\title{
Literacy in the Era of 4.0 Industrial Revolution in Listening Skill Based on Local Wisdom Video in Elementary School
}

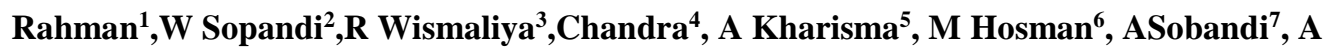 \\ Sumiati $^{8}$

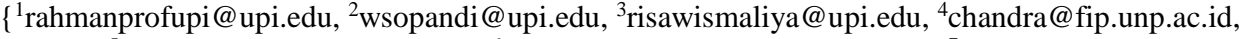 \\ 5 annisakharismaupi@upi.edu, 6 hosnan_international@gmail.com, 7ade@upi.edu, \\ 8aisumiati1960@gmail.com\} \\ ${ }^{1,2,3,7}$ Universitas Pendidikan Indonesia, Indonesia \\ ${ }^{4}$ Universitas Negeri Padang, Indonesia \\ ${ }^{5}$ Universitas Islam Negeri Imam Bonjol Padang, Indonesia \\ ${ }^{6}$ Universitas Negeri Tirtayasa Serang, Indonesia \\ ${ }^{8}$ Dinas Pendidikan Kabupaten Sukabumi, Indonesia
}

\begin{abstract}
Abstarct. The low literacy of students' listening skill in Indonesia in the era of 4.0 industrial revolution are the center of attention for all education observers today. This is proven by the results of research conducted by Central Connecticut State University (CCSU) in 2017, which placed Indonesia's position ranked 60th out of 61 countries. In addition, problems were also found in listening skills in elementary schools, included: (1) The low of students' listening skill were due to several factors: students' attitude that lowered to the listening skill, a large number of students also influenced the learning environment to be not conducive, and lack of interaction in classroom learning; (2) the learning process in the classroom is still minimal in showing the existence of literacy culture; and (3) lack of local wisdom video media utilization so that the learning process becomes unpleasant for students. Based on these problems, it is necessary to study more seriously the implementation of literacy in the 4.0 industrial revolution era in the context of listening. One of the efforts to overcome the problems and achieve the research objectives is by implementing the literacy based on local wisdom video. This type of research uses a quantitative approach and is quasi experimental research. The results of the research on the implementation of literacy in the era of 4.0 industrial revolution based on local wisdom video can improve students' literacy skills in the context of listening.
\end{abstract}

Keywords: Literacy, Listening, Local Wisdom, Elementary School

\section{INTRODUCTION}

The listening skill of elementary school students in Indonesia is so low in the learning process. Students can only keep listening for 10-15 minutes. Even though the experts estimate that $85 \%$ of what is known to humans come from listening [1]-[3]. Listening activities are activities that are not interesting, boring, and time-consuming for students. Students' saturation 
in listening occurs because they feel forced to do the listening activities whereas the benefits of listening activities are very important for human life.

The results of the study about literacy conducted by Central Connecticut State University (CCSU) in 2017 put Indonesia in the $60^{\text {th }}$ position out of 61 countries, a level above Botswana. Statistical data from the United Nations Educational, Scientific, and Cultural Organization (UNESCO) in 2017 also explains that of a total of 61 countries, Indonesia is the $60^{\text {th }}$ rank with a low literacy level. In the $59^{\text {th }}$ rank is Thailand and the last rank is Botswana. Whereas Finland was in the first rank with a high literacy rate reaching 100\% [4]-[11].

The low level of Indonesian literacy, especially listening skills, also has an impact on Indonesia's education level. Reporting from the data research that conducted by the United Nations Development Program (UNDP), the level of education based on the Human Development Index (HDI) in Indonesia is still relatively low, at $14.6 \%$. This percentage is much lower than Malaysia which reached 28\% and Singapore reached 33\% [6], [9], [12], [13].

In the scope of education, listening is the basis of skills in oral communication. If a person's ability to listen is lacking, it is certain that he/she cannot reveal a topic that is well heard. Listening activities can be seen from daily life that are faced with a variety of listening activities, for example in dialogues between family members, interpersonal conversations, and educational activities in schools [14]-[16].

Many people do not understand that listening is as active as speaking, even in some ways it is far more complicated and difficult. The speakers know clearly the message to be said, while the listeners must interpret the message to be conveyed. Listening well requires attention, thought, reasoning, interpretation, and imagination of listeners. Listeners must project themselves into the speaker's mind and try to understand not only what the speaker says, but also the message that they intended [15], [17], [18].

This research emphasizes more on the literacy implementation in listening skill in elementary school. The problems in literacy implementation in listening skill in elementary school are: (1) The low of students' listening skill are due to several factors: students' attitude that lowered to the listening skill, the large number of students also influenced the learning environment to be not conducive, and lack of learning interaction in the classroom; (2) The learning process in the classroom is still minimal in showing the existence of literacy culture; and (3) The lack of local wisdom video media utilization so that the learning process becomes unpleasant for students and it does not come from their own environment [19]-[21].

The implementation of literacy in the learning process has a tremendous influence on the students' listening skill progress in elementary school. Literacy is development in all forms that allow students to understand how language works in different social contexts and critically assess opinion writing, guesswork, and meaning, and help students in making sophisticated language choices in the texts they produce themselves, so that they become a sensitive person to social and cultural things [8], [22], [23].

The following are things that the students must master for literacy understanding : (1) literacy as an autonomous set of skills; (2) literacy as an application, practiced, and held; (3) literacy as a learning process; and (4) literacy as the text produced [4], [6], [10], [24]. The implementation of literacy in Indonesia is certainly adapted to current technological developments of 4.0 industrial revolution.

The 4.0 industrial revolution is characterized by the increasingly complex relationship between human life and technology. Humans can use technology more than the achievements that have been made today, even the use of technology now is still categorized on a small scale. The 4.0 industrial revolution can design the latest use of technology which will have a considerable impact on human life. In this study, the implementation of literacy in the 4.0 
industrial revolution will be assisted by a learning media namely video. This research used video based on local wisdom of children's stories in order to preserve local culture and be close to students' real lives.

\section{RESEARCH METHOD}

This research uses a quantitative approach and is also quasi-experimental research which is used to find the effect of literacy implementing based on a video in listening and writing skills of fifth-grade students in elementary school, with a design from Sugiyono which is nonequivalent design. The subjects in this study were the fifth-grade students in SD Laboratorium Percontohan UPI. The subject research technique was purposive sampling, which is sampling which aims to examine a particular research subject from a condition [25].

This study uses two kinds of data collection techniques, through observation and written tests (test synopsis writing). The development of behavior and social adjustment, interests, and talents of students and teacher activities development in listening and writing learning using the literacy implementation based on video was obtained from the analysis results of the observation sheet of teacher and student activities. To out the students' listening and writing skill using the find implementation based on the video, the instruments provided were in the form of limited description tests. Through this technique, researchers assign students, both in the control class and in the experimental class. The prose writing test is done twice. The first test was the pretest given before the research was given to the two sample groups. The second test is the final test (posttest) which was given after the research. The researchers gave a literacy implementing treatment based on video for the experimental class, while the control class carries out the learning process with conventional learning (the usual learning which is provided by the teacher at the school).

The data processing techniques are using descriptive methods and statistical methods. Descriptive methods are used to describe research data. Statistical methods are used for the purposes of processing quantitative data such as data requirements testing and hypothesis testing. After the statistical data is obtained then making conclusions to interpret the meaning. Quantitative data in this research were processed with SPSS statistical software for windows.

\section{RESULT AND DISCUSSION}

Based on the results of pretest-posttest which were conducted in the experimental group and the control group with each consisting of 42 students of fifth grade in SD Negeri Percontohan UPI. The results of the pretest show that every student had initial knowledge before the learning process took place. The initial knowledge of students related to the concept of listening to material content. Students are directed to listen to the local wisdom videos related to children's stories. For each listening concept related to children's stories, there are variations in conception between three to five types of conception. This shows that every student enters the class, not in a blank mind, but has had various ideas about a concept relating to the children's story and how to listen. The following are the results of the pretest-posttest in the experimental group and the control group in the fourth grade of SD Negeri Percontohan UPI. 
Table 1. The results of the pretest-posttest in the experimental group and the control group in the fourth grade of SD Negeri Percontohan UPI

\begin{tabular}{ccccc}
\hline Number of & \multicolumn{2}{c}{ Class Control } & \multicolumn{2}{c}{ Experimental Class } \\
Students & Pre Test & Post Test & Pre Test & Post Test \\
average & 62.43 & 66.76 & 62.60 & 82.19 \\
\hline
\end{tabular}

Based on the results of the pretest and posttest in the two groups there was a change in the score. In the experimental group, before the treatment, all members were in a low category. The average score before treatment is 62.60 Whereas, after the treatment, the average score increased by $31 \%$ reaching 82.19 . Whereas in the control group, the average score before treatment was 62.43 with all students in the low category. This control group did not get treated like the experimental group, there was an increase in score of $7 \%$ reaching 66.76 in the control group.

Listening skills learning by using local wisdom videos of children's stories in literacy had eight meeting sessions according to literacy needs. The preparation for the implementation of literacy learning starts from the pretest giving and continues with the lesson plan of listening skills learning based on video of children's stories local wisdom. In this research, literacy learning in listening skill based on video of children's stories local wisdom was delivered to two teachers and one school principal in the form of Focus Group Discussion activities. The learning implementation in the control class is listening skill learning based on the picture, while in the experimental class used listening skill learning based on video of children's stories local wisdom in elementary school.

Based on the results of 4.0 industrial revolution literacy research in listening skill based on video of children's stories local wisdom in elementary school was found that the video of children's stories local wisdom influenced the literacy skills and listening skills of students in elementary school. The students in the control class and in the experimental class did the correct listening stages. The following are the stages in listening ; (1) Stage of listening, at this stage we just hear everything that is said by the speaker in the speech or conversation. So we are still in the hearing stage[26], [27]. (2) The stage of understanding, after we hear, there is a desire for us to understand or understand the contents of the conversation which are delivered by the speaker[11], [28]. (3) The stage of interpreting, listeners who are good, careful and thorough, are not satisfied if they only hear and understand the contents of the speaker's speech. They want to interpret or interpret the content, points of opinion which are implied in that statement[29], [30]. (4) The stage of evaluating, after understanding and interpreting the contents of the speaker, the listener begins to evaluate or evaluate the opinions and ideas of the speaker, the strengths and weaknesses of the speaker, and the good and bad of the speaker[31], [32]. (5) The stage of responding, it is the final stage in listening activities. The listener welcomes, remembers, absorbs and accepts the ideas or ideas which are expressed by the speaker in his speech or conversation [15], [33].

The fourth grade students of SD Negeri Percontohan UPI who experienced the learning process of listening skills by using the video of children's stories local wisdom got some benefits, the following are the benefits ; (1) Adding valuable knowledge and life experiences to students' abilities, because listening has informative value, that is giving input that makes us become experienced. (2) Enhancing intellectuality and deepening the appreciation of science and repertoire of knowledge. (3) Enriching vocabulary, adding the appropriate, quality, and poetic vocabulary. People who listen a lot, their communication becomes smoother and they have a lot of words in communication. (4) Extending insight, increasing life appreciation, and fostering an open and objective mind. (5) Increasing social sensitivity and care. Through 
listening, we can get to know the ins and outs of life in all its dimensions. With better materials, it can make us reflect on the value of life so that we are encouraged to solve existing problems, according to our abilities. (6) Enhancing artistic image, it means if we see is a recipe material whose contents are smooth and the language is beautiful. A lot of listening can foster an appreciative attitude, respect the work or opinions of others and this life and also enhance aesthetic tastes. (7) Inviting quality and the spirit of us to produce good utterances and writings. If we listen a lot we will get brilliant ideas and valuable life experiences.

The results of the research show that the literacy process in listening skill using the video of children's stories local wisdom produced a better listening skill than using pictures. Video of children's stories local wisdom is a media that have sound element and picture element and it can deliver information from the sources of information to the information recipients [34].

\section{CONCLUSIONS}

Literacy in the era of 4.0 industrial revolution in listening skill based on video of children's stories local wisdom in elementary school can provide learning outcomes that are more satisfying than learning using images. Local wisdom videos can be used to be adjusted to harmonize student relations with the environment as the goal of complete human development, to use natural resources wisely and in a controlled manner, to shape Indonesian people who love and act as environmentalists, and protect the country from various external influences that can damage and pollute the environment. The benefit of listening to the local wisdom of children's stories in this research is to add valuable knowledge and life experiences to humanity and to know their own culture, evaluate so that they can assess the material, improve and foster appreciation, and get entertainment through children's stories, and obtain local cultural values that lead to the positive character of the nation.

\section{ACKNOWLEDGMENTS}

The author gives awards to the leaders of Universitas Pendidikan Indonesia who have funded this research. The author also thanked the Percontohan elementary schoolleaders who had provided time for research.

\section{REFERENCES}

[1] J. P. Gee, "What Video Games Have to Teach Us About Learning and Literacy," ACM Comput. Entertain., vol. 1, no. 1, pp. 1-4, 2003.

[2] E. Rodgers, J. V. D’Agostino, S. J. Harmey, R. H. Kelly, and K. Brownfield, "Examining the Nature of Scaffolding in an Early Literacy Intervention," Read. Res. $Q$. , vol. 51, no. 3, pp. 345-360, 2016.

[3] L. Northrop, "Breaking the Cycle: Cumulative Disadvantage in Literacy," Read. Res. Q., vol. 52, no. 4, pp. 391-396, 2017.

[4] M. Tok, "Examining pre-service teacher views on the implementation of screen-based writing instruction," Int. Electron. J. Elem. Educ., vol. 7, no. 2, pp. 235-252, 2015.

[5] E. B. Moje, T. Collazo, R. Carrillo, and R. W. Marx, "Maestro, what is "quality"?': Language, literacy, and discourse in project-based science," J. Res. Sci. Teach., vol. 38, no. 4, pp. 469-498, 2011.

[6] Muhammadi, Taufina, and Chandra, "Literasi Membaca Untuk Memantapkan Nilai Sosial Siswa SD,” LITERA, vol. 17, no. 2, pp. 202-212, 2018. 
[7] W. E. Blanton, K. D. Wood, and D. B. Taylor, "Rethinking Middle School Reading Instruction: A Basic Literacy Activity," Read. Psychol., vol. 28, no. 1, pp. 75-95, 2007.

[8] S. Thomson, K. Hillman, and L. De Bortoli, "A teacher's guide to PISA reading literacy," 2013.

[9] Muslimin, "Foster A Culture Of Literacy Through Increased Reading Interest In Village Communities," Cakrawala Pendidik., vol. 37, no. 1, pp. 107-118, 2018.

[10] Taufina and Chandra, "Developing The Big Questions And Bookmark Organizers ( BQBO ) Strategy - Based Literacy Reading Learning Materials In The 4 Th Grade Of Elementary School," Int. Conf. Sci. Educ. Teach., vol. 118, no. 5, pp. 857-864, 2017.

[11] J. L. Below, C. H. Skinner, J. Y. Fearrington, and C. A. Sorrell, "Gender Differences in Early Literacy: Analysis of Kindergarten through Fifth-Grade Dynamic Indicators of Basic Early Literacy Skills Probes,” School Psych. Rev., vol. 39, no. 2, pp. 240-257, 2010.

[12] T. Harsiati, "Karakteristik Soal Literasi Membaca Pada Program PISA," LITERA, vol. 17, no. 1, pp. 90-106, 2018.

[13] Nurchasanah and S. H.S., "Perangkat Perkuliahan Pembelajaran Literasi Berbasis ELearning," Bhs. dan Seni, vol. 44, no. 2, pp. 224-240, 2016.

[14] C. Meskill, "Listening Skills Development Through Multimedia," J. Educ. Multimed. Hypermedia, vol. 5, no. 2, pp. 179-201, 1996.

[15] L. Miller, "Developing Listening Skills with Authentic Materials," ELC 689 English as a Foreign Lang. Assess. Contin. Prof. Stud. UMBC, 2003.

[16] P. Brett, "Multimedia For Listening Comprehension: The Design Of A MultimediaBased Resource For Developing Listening Skills," Sytem, vol. 23, no. 1, pp. 77-85, 1995.

[17] J. V. D'Agostino, E. Rodgers, and S. Mauck, "Addressing Inadequacies of the Observation Survey of Early Literacy Achievement," Read. Res. Q., vol. 53, no. 1, pp. 51-69, 2018.

[18] S. C. Kalindi, C. McBride, and L. Dan, "Early Literacy Among Zambian Second Graders: The Role of Adult Mediation of Word Writing in Bemba," Read. Res. Q., vol. 53, no. 1, pp. 7-27, 2018.

[19] S. Nirmala, Rahman, and B. Musthafa, "Comparing Students' Critical Thinking Elementary School in Different Area with Utilizing FIVES Strategy," Adv. Sci. Lett., vol. 24, no. 11, pp. 8357-8360, 2018.

[20] T. N. Hayati, Rahman, J. Sunanto, and T. Y. Pratama, "The Assessment of Communication Ability on Deafblind Students," Adv. Sci. Lett., vol. 25, no. 1, pp. 126-129, 2019.

[21] R. D. Puspita and Rahman, "A Meningkatkan Kemampuan Membaca Pemahaman Berbantuan Pembelajaran Tematik Terpadu Bernuansa Model InteractiveCompensatory.," Pendas J. Ilm. Pendidik. Dasar, vol. 2, no. 2, pp. 200-211, 2017.

[22] R. Baleiro, "A definition of literary literacy: A content analysis of literature syllabuses and interviews with Portuguese lecturers of literature," TOJNED Online J. New Horizons Educ. Oct. 2011, vol. 1, no. 4, 2011.

[23] C. Mimeau, J. Ricketts, and S. H. Deacon, "The role of orthographic and semantic learning in word reading and reading comprehension," Sci. Stud. Read., vol. 00, no. 00, pp. 1-17, 2018.

[24] Y. Chang and P. Monaghan, "Quantity and Diversity of Preliteracy Language 
Exposure Both Affect Literacy Development : Evidence from a Computational Model of Reading Quantity and Diversity of Preliteracy Language Exposure Both Affect Literacy Development : Evidence from a Computatio," Sci. Stud. Read., vol. 23, no. 3, pp. 235-253, 2019.

[25] J. R. Fraenkel, N. E. Wallen, and H. H. Hyun, How to design and evaluate research in education (8th ed.). New York: McGraw-Hill, 2012.

[26] H. Hughes, N. Hall, and M. Pozzie, "Library Experience and Information Literacy Learning of First Year Internat...: EBSCOhost," Commun. Inf. Lit., vol. 11, no. 2, pp. 302-323, 2017.

[27] A. Girli and H. Öztürk, "Metacognitive reading strategies in learning disability: Relations between usage level, academic self-efficacy and self-concept," Int. Electron. J. Elem. Educ., vol. 10, no. 1, pp. 93-102, 2017.

[28] S. Levine, "Using Everyday Language to Support Students in Constructing Thematic Interpretations," J. Learn. Sci., vol. 28, no. 1, pp. 1-31, 2019.

[29] X. Meyer, "Productive disciplinary engagement as a recursive process: Initial engagement in a scientific investigation as a resource for deeper engagement in the scientific discipline," Int. J. Educ. Res., vol. 64, pp. 184-198, 2014.

[30] R. Savage, G. Georgiou, R. Parrila, and K. Maiorino, "Preventative Reading Interventions Teaching Direct Mapping of Graphemes in Texts and Set-forVariability Aid At-Risk Learners," Sci. Stud. Read., vol. 00, no. 00, pp. 1-23, 2018.

[31] P. T. Daniels and D. L. Share, "Writing System Variation and Its Consequences for Reading and Dyslexia," Sci. Stud. Read., vol. 22, no. 1, pp. 101-116, 2018.

[32] T. Farsides, P. Sparks, and D. Jessop, "Self-reported reasons for moral decisions," Think. Reason., vol. 24, no. 1, pp. 1-20, 2018.

[33] D. Kuhn and A. Modrek, "Do reasoning limitations undermine discourse?," Think. Reason., vol. 24, no. 1, pp. 97-116, 2018.

[34] K. Saddhono and M. Rohmadi, "A Sociolinguistics Study on the Use of the Javanese Language in the Learning Process in Primary Schools in Surakarta, Central Java, Indonesia." Int. Edu. Stu., vol. 7 no.6 pp 25-30, 2014 